\title{
The Effect of Using Word Family Game on The Vocabulary Mastery of The Fifth Grade Students at SD Negeri 1 Astina in Academic Years of 2017/2018
}

\author{
Kartadi, Ni Komang Amelia \\ English Education Department, Universitas Pendidikan Ganesha \\ ameliakartadi@yahoo.com
}

\begin{abstract}
This study aimed at investigating of the effect of using word family game committed by the fifth grade student in SD Negeri 1 Astina in mastering the English vocabulary. This study was True-Experimental with post-test only control group design. The population was 59 students of the fifth grade and the sample was selected by using cluster random sampling. The sample of this research study was 22 students in 5A as an Experimental Group while 22 students in 5B as a Control Group. The experimental group was taught by using Word Family Game and control group was taught without using Word Family Game. The data was analyzed descriptively and inferentially through SPSS 16.0 Program. Descriptively, the students in experimental group were achieved better than the students in control group. It was proven by the result of the mean score of the experimental group was 90.45, while the mean score of control group was 83.18. The result of the t-test also showed that the score of the (tobs) was 3.393 which the score of (tcv) was 1.682 which based on the degree of freedom was 42 . It showed that the (tobs) $>$ (tcv), where: $3.393>1.682$. It could be concluded that the word family game had a significant effect on the students' vocabulary mastery rather than using conventional teaching.
\end{abstract}

Keyword: Word Family Game, Vocabulary Mastery

\section{Introduction}

Vocabulary mastery is very influential to English learners in their efforts to learn the language. It can be considered as the basic for being able to communicate through spoken and written interaction. Without sufficient vocabulary, the learner cannot understand a reading text or produce a writing text and also cannot either comprehend a speech or produce an utterance. According to Rojananak and Vitayapirak (2015:01) since vocabulary learning is part of language learning and teaching, it is also worth mentioning in the present study that strategies should be indispensable parts of vocabulary learning and teaching.

Teaching vocabulary is not an easy work. Teacher should find the best or the effective technique to teach English vocabulary. According to Dewi (2013:1) in real teaching and learning process, vocabulary is still being a problem for both of teacher and the students. It means before the teacher going to teach the students in mastering English vocabulary, the teacher should be knowledgeable or master in English vocabulary first. Many students fail in learning English because they have less English Vocabulary.

Teaching English in a fun and interesting way is one of an appropriate way to teach the students at primary level. In some of elementary school in Indonesia have not teach yet about the important of learning English language to the students. It shows that the students in preliminary level are still lack of the knowledge of an English language especially in mastering the vocabulary. Media as teaching aids are needed to help students' understanding and to increase the effectiveness in the communication between teacher and students in teaching and learning process. It is also used to stimulate the students' motivation and students' interest to the lesson.

One of the beneficial media in improving students' mastery of vocabulary is the words family. By applying words family game hopefully could help the students in remembering the vocabulary without feeling that they are very serious in studying. Through the habit such as 
looking the words technique, indirectly they remember the vocabulary. Actually, word which is used by the students is always the same word around their conversation of their daily activities which consist of noun, verb, adjective and adverb. The teacher only has to improve student's vocabulary by suitable Game such as Words Family Game.

The writer chooses Word Family game because empirically, in some of Indonesian schools have not been applied yet a Word Family Game especially in Bali. Furthermore, the writer wants to investigate whether or not it has significant effect on students' vocabulary mastery. Besides, Word Family Game already applied in other areas by some of researcher and it shows that this game give an impact on students' vocabulary mastery. Therefore, the writer will apply this game in one of school in Bali named SD Negeri 1 Astina.

SD Negeri 1 Astina is located at Gajah Mada Street number 37, Buleleng Sub-District. Based on the preliminary observation conducted by the writer found that the number of the students at SDNegeri1 Asrina of fifth Grade student is 54 and consist of 2 classes they are 5A and 5B class. Based on the interview with one of English teacher in that school stated that, she found some difficulties in teaching English, due to English as a foreign language makes the students in this school difficult to learn a new language, where their mother tongue is Bahasa.

Based on the aforementioned statement, Word Family Game will be tried out whether or not it has significant effect of using words family Game on Students' Vocabulary Mastery. Considering with the previous research conducted by Fak iyah (2015) shows that Word Family Game can help the students to improve their vocabulary mastery. As the result, the writer will conduct a research about this study in SD Negeri 1 Astina, where the Word Family Game as an independent variable is to measure the students' Vocabulary Mastery and Vocabulary Mastery is the dependent variable that will be measured as the result in applying the independent variable. The population of this study is students in the fifth grade and the researcher will choose 2 classes which are chosen by Cluster randomly sampling from the total number of students in fifth grade is 59 and contained of 2 classes; those are 5A and 5B.

\section{Method}

The setting of this research is in SD Negeri 1 Astina Singaraja sub-distrit. The population is the fifth grade students in academic years of 2017/2018 and for the sample of this study is 22 students in 5A while 22 Students in 5B. The procedure in conducting this research is formulated as follows:

1) Determining the population of the study, and the chosen population was the fifth grade students of the first semester.

2) Selecting the two classes of the fifth grade in SD Negeri 1 Astina by using cluster random sampling.

3) Deciding both classes which one as control group and which one as experimental group through lottery.

4) Preparing the instrument for collecting the data further.

5) Both classes was given different treatment, Experimental group was treated by using Word Family Game, while the control group did not treated by using Word Family Game.

6) Administering the experiment and control group was tested with the same instrument after giving the treatment.

7) Analyzing the result of the post-test score by using descriptive statistic and inferential analysis through SPSS 16.0 Program.

8) Summarizing the result of the study to determine the effect of Word Family Game on the students' vocabulary mastery of the fifth grade students in SD Negeri 1 Astina Singaraja. 


\section{Findings and Discussions}

\section{Findings}

Tabel 1 . The quality of the obtained data frequencies

\begin{tabular}{|c|c|c|c|}
\hline \multirow{7}{*}{$\begin{array}{l}\text { Mean Score } \\
\text { (Experimental) } \\
: 90,45\end{array}$} & & Interval Score & Category \\
\hline & & $95,0-100,0$ & Excellent \\
\hline & & $91,7-94,9$ & Good \\
\hline & 90,45 & $88,3-91,6$ & Average \\
\hline & & $85,0-88,2$ & Bellow Average \\
\hline & & $80,0-84,9$ & Poor \\
\hline & & Interval Score & Category \\
\hline \multirow{6}{*}{$\begin{array}{l}\text { Mean Score } \\
\text { (Contro) } \\
: 83,18\end{array}$} & & & \\
\hline & & $92,5-100,0$ & Excellent \\
\hline & & $87,5-92,4$ & Good \\
\hline & & $82,5-87,4$ & Average \\
\hline & & $77,5-82,4$ & Below Average \\
\hline & 83,13 & $70,0-77,4$ & Poor \\
\hline
\end{tabular}

Tabel 2. The result of the t-test

\begin{tabular}{|c|c|c|c|c|c|c|c|c|c|c|}
\hline \multicolumn{11}{|c|}{ Independent Samples Test } \\
\hline & & \multicolumn{2}{|c|}{$\begin{array}{l}\text { Levene's Test } \\
\text { for Equality } \\
\text { of Variances }\end{array}$} & \multicolumn{7}{|c|}{ t-test for Equality of Means } \\
\hline & & \multirow[t]{2}{*}{$\mathrm{F}$} & \multirow[t]{2}{*}{ Sig. } & \multirow[t]{2}{*}{$\mathrm{t}$} & \multirow[t]{2}{*}{ df } & \multirow[t]{2}{*}{$\begin{array}{l}\text { Sig. (2- } \\
\text { tailed) }\end{array}$} & \multirow[t]{2}{*}{$\begin{array}{l}\text { Mean } \\
\text { Differe } \\
\text { nce }\end{array}$} & \multirow{2}{*}{$\begin{array}{l}\text { Std. } \\
\text { Error } \\
\text { Differe } \\
\text { nce }\end{array}$} & \multicolumn{2}{|c|}{$\begin{array}{l}\text { 95\% Confidence } \\
\text { Interval of the } \\
\text { Difference }\end{array}$} \\
\hline & & & & & & & & & Lower & Upper \\
\hline $\mathrm{SCO}$ & Equal & ,209 & ,650 & - & 42 & ,002 & $-7,273$ & 2,144 & $-11,599$ & $-2,947$ \\
\hline \multirow{5}{*}{ RE } & variances & & & 3,39 & & & & & & \\
\hline & assumed & & & 3 & & & & & & \\
\hline & Equal & & & - & 41,5 & ,002 & $-7,273$ & 2,144 & $-11,600$ & $-2,945$ \\
\hline & variances not & & & 3,39 & 05 & & & & & \\
\hline & assumed & & & 3 & & & & & & \\
\hline
\end{tabular}

\section{Discussion}

Based on the data obtained showed that the experimental group which was treated using word family game achieved higher scores than the data obtained which is showed in control group. It could be seen from the mean score between experimental was 90.45 and control group was 83.18. Meanwhile, concerning to the result of inferential statistical analysis, it was found that the obtained significance two-tailed score was 0.002 or lower than the alpha value $(\alpha)$ at the degree of freedom 42 . Thus, the researcher determined that there is significant effect of using word family game on the students' vocabulary mastery of the fifth grade student. Moreover, the use of word family game as a strategy of teaching English vocabulary is effective to help the teacher improve the students' English vocabulary.

The result of the experimental group which showed the effectiveness of using word family game as a strategy of teaching English vocabulary could happen because of the fun and enjoyable learning process. In the line with statement of Kunnu, Uiphanit and Sukwises (2016: 419) games are the methods to practice English, which are significantly effective in 
learning language as learners are fun in learning, making the learners feel enthusiasm and courage to use English.

The findings also answered the statements of the problem of this research which is to know the effect of using word family game on the students' English vocabulary mastery of the fifth grade students and it also supported by the result statistically of the pos-test for both experimental group and control group.

Empirically, the use of game as a strategy of teaching English vocabulary was already investigated by the other researchers. Firma in (2010) proved that there is a significant effect of using game on students' vocabulary mastery of the seventh grade students of SMP Islam Durenan. In line with that statement, there is Fauziah in (2011) showed the data result that there is significant effect of using picture in increasing students' vocabulary mastery. Where, picture is one of media of teaching that could help the students in learning English especially in increasing the new vocabulary by seeing the pictures given.

Furthermore, based on the research study conducted by Damayanti in 2014 showed that there is significant effect of using word search puzzle game on students; vocabulary mastery. It means that word search puzzle game is suitable game to increase students' vocabulary mastery of the fifth grade students of SD Negeri 01 Ngaglik, Blitar. Thus, the game is appropriate to use to teach English vocabulary in the elementary grade students.

Theoretically, Al Nasri and Al Najar (2014:145) Games bring in relaxation and fun for students, thus help them learn and retain new words more easily. Games also usually involve friendly competition and they keep learners interested. Thus, game can help the students to be more active in the class. Al Nasri and Al Najar also stated that games are highly motivating and they give students more opportunity to express their opinions. According to Donmus in Chalak and Ahmadi (2017: 78) games provided students with the opportunity to reinforce the previous knowledge by repeating it in a more comfortable environment. Educational games are software that helps students to learn the lesson topics and develop their problem solving skills by using their desire and enthusiasm to play. Furthermore, the word family game as one of media teaching English vocabulary can help the students to learn a new language. It proved by Iyah (2015: 31) which conducted a research study about the use of word family in teaching English vocabulary, from the result showed that word family game could bring an active and fun learning activity. The students also learn to be better in teamwork and to be a good leader in the team.

Mulling to the relation between the result of the study and the empirical review, there is also the theory which is stated by Duke and Moses (2003:6) playing a game such a fun media of teaching during the learning process simply encouraging the students to be more enthusiasm in exploring their knowledge of words and its meaning. Meanwhile, from those all empirical review which is conducted the same strategies of teaching such as game, showed that have a significant effect on the students English vocabulary. Thus, comparing between teaching conventionally, teaching English vocabulary to the students of elementary grade and teaching by using game especially word family game, give a significant effect in helping the students in remembering a new word and learn to build a complete sentences.

In this research study, the researcher taught of the experimental and control class by teaching scenario. The teaching scenarios in both classes were almost same, but the different is only in the techniques of giving the treatment, where the control group were only taught conventionally or without using such of game, but in experimental group were taught by giving such of game which is namely word family game. It could be said that, the 5B of SD Negeri 1 Astina were taught without using word family game, meanwhile the 5A of SD Negeri 1 Astina were taught by using word family game. 
In the teaching process of experimental group, the researcher was using communicative approach, the method was communicative language teaching, the techniques was word family game, group discussion, and question and answer. Meanwhile, in the control group, the researcher was using communicative approach, communicative language teaching method, and for the techniques of teaching, the researcher gave the students drill, group discussion and exercises. For every student in both experiment and control group achieved a similar feedback that was by answer or respond the students questions or answer, giving some comments to their worksheet, giving some advices while teaching and also appreciate them in a good way to motivated them in learning more and more.

After all the students' score of post-test was collected and completed, the researcher analyzed the data collection descriptively and for the result of the experimental group showed the mean score is 90.45 and for the control group is 83.18. The standard deviation of experimental group is 6.710 and for the control group is 7.487. From those findings, the data obtained showed that the experimental achieved score better than the control group. Inferentially, the data showed that the score of Sig. (2-tailed) was .002 or 0.002 in degree of freedom was 42 which means the significance 2-tailed test was lower than the alpha value $(\alpha)$ which is 0.05 or .05 (5\%). It could be seen in the score of the (tobs) is 3.393 which the score of (tcv) is 1.682 which is based on the degree of freedom is 42. It shows that the (tobs) > (tcv), where: $3.393>1.682$. Therefore, the null hypothesis was rejected and the alternative hypothesis was accepted. It means, there is significant effect of using word family game on the students' English vocabulary mastery at the fifth grade students of SD Negeri 1 Astina Singaraja sub-district in academic year of 2017/2018. It also proven and strengthened by the result of the previous researcher which is conducted the same study, as well as the theories that support and stated in this research study.

\section{Conclusion}

Based on the data showed from the mean score achieved by the experimental group is better than the control group (90.45>83.18). the most importantly showed from the inferential statistical analysis showed that the score of Sig. (2-tailed) was .002 or 0.002 in degree of freedom was 42 which means the significance 2-tailed test was lower than the alpha value $(\alpha)$ which is 0.05 or .05 (5\%). It could be seen in the score of the (tobs) is 3.393 which the score of (tcv) is 1.682 which is based on the degree of freedom is 42. It shows that the (tobs) > (tcv), where: $3.393>1.682$. Therefore, the null hypothesis was rejected and the alternative hypothesis was accepted.

Thus, it could be said that, there is significant effect of using word family game on the students' English vocabulary mastery at the fifth grade students of SD Negeri 1 Astina Singaraja sub-district in academic year of 2017/2018.

\section{References}

Anil, Beena. (2011). Teaching Vocabulary through Games-A Sanguine Step. i-Manager's Journal on English Language Teaching, Vol. 1. No. 4.Chennai: SDNB Vaishnav College.

Astutik, Ika Fitria. (2015). The use of word search game to developStudents' mastery of vocabulary of the seventhYear students of MTS Tarqiyatul Himmah in the Academic year of 2013/2014. Salatiga: State Institute for Islamic Studies (IAIN)

Chalak, Azizeh and Behzad Ahmadi. M. A. (2017). Integration of Serious Games in Teaching English as a Foreign Language to Iranian Children. International Journal of Foreign 
Language Teaching \& Research - Volume 5, Issue 17. Isfahan: Islamic Azad University.

Dewi, Ni Made Adiarti. (2013). Improving vocabulary mastery through word collection game of the eighth grade students of SMP Sapta Andika Denpasar in Academic year 2012/2013. Denpasar: Universitas Mahasaraswati.

Duke, Nell and Moses, A. (2003). 10 research tested ways to build children's vocabulary.

Ertmer, P.A. and T.J. Newby. (2013). Behaviorism, Cognitivism, Constructivism: Comparing Critical Features from an Instructional Design Perspective

Fauziati, Endang. (2005). Teaching of English as a Foreign Language. Surakarta: Muhammadiyah University Press.

Frima, Amiati Dwi. (2010). The effectiveness of using pictorial puzzle in improving vocabulary of seventh grade students of SMP Islam Durenan. Tulungagung: English Education Program, STAIN

Iyah, Fak. (2015). The use of word families game to improve the students' vocabulary mastery on the first grade students' of SMK PGRI 2 Salatiga. Salatiga: State Institute for Islamic Studies.

Kamil, M., \& Hiebert, E. (2005). Teaching and learning vocabulary: Bringing research to practice. Mahwah, New Jersey: Lawrence Erlbaum Associates.

Kunnu, Wichuda, Thanakorn Uiphanitand and Aungkana Sukwises. 2016. The Development of Vocabulary Memorization by Using Games.International Journal of Social Science and Humanity, Vol. 6, No. 6. DOI: 10.7763/IJSSH.2016.V6.683

Mofareh, Alqahtani. (2015). The Importance Of Vocabulary In Language Learning And How To BeTaught .International Journal Of Teaching And Education, Vol. Iii(3),Pp. 21-34., 10.20472/Te.2015.3.3.002 21

Nation, I. S. P. (2001). Learning vocabulary in another language. Cambridge: Cambridge University Press.

Nilawati, Sofika Chandra. (2008). The Effectiveness Of Teaching Vocabulary By Using Puppet At Elementary School Students (The Case Study Of The Fourth Graders Of SDN Leteh II Rembang in The Academic Yearof 2007/2008). Semarang: A thesis, English Departmennt, Faculty of Languages and art, Semarang State Uneveristy. Retrieved: http://lib.unnest.ac.id/852/1/2185.pdf

Rojananak, Khanadee \& Jirapa Vitayapirak. (2015). Comparison of English Vocabulary Learning Strategies for Good and Weak Learners at King Mongkut's Institute of Technology Lad krabang. International Journal of Languages, Literature and Linguistics, Vol. 1, No. 1. DOI: 10.7763/IJLLL.2015.V1.1

Sukmawati. (2006). The Correlation between Vocabulary Mastery and Speaking Skill of The Second Year Students of SMA Negeri 4 Palu.Thesis. Palu: UNTAD Unpublished.

Thornbury, Scott. (2002). How to Teach Vocabulary. London: Longman 